\title{
Impact of a marina construction on a seagrass bed at Lanzarote (Canary Islands)
}

\author{
Tuya, F.; Martín, J.A. \& Luque, A. \\ Departamento de Biología, Universidad de Las Palmas de Gran Canaria, 35017, Campus de Tafira s/n, Las Palmas de \\ Gran Canaria, Spain; *Corresponding author; Fax 34 928452922; E-mail ftuya@yahoo.es
}

\begin{abstract}
Interannual changes in the shoot density, biomass and leaf length of the seagrass Cymodocea nodosa and two descriptors of the associated fish communities (total fish abundance and species richness) were evaluated at Playa Blanca (Lanzarote, Canary Islands) from March 2001 to April 2002 to provide evidence for responses to the impact of a marina construction. The seagrass bed under influence, as well as a control location, were sampled using an experimental design which consisted of three sites nested within each of these two locations. We tested the null hypothesis that these parameters would not change over time as a result of this construction.

A three-way mixed and symmetrical ANOVA detected significant 'Time of sampling $\times$ Control vs Impact' interactions for the shoot density, biomass and leaf length. The same interactions were observed for the descriptors of the fish communities using a two way orthogonal ANOVA. We detected an initial fast increase in the mean leaf length as a possible morphological response to a reduction in the amount of light at the bottom. Furthermore, a significant decrease was obtained for the penetration of light into the water column in the perturbed bed. Therefore, we obtained significant evidence to reject the null hypothesis offered by our study.
\end{abstract}

Keywords: Anthropogenic perturbation; Cymodocea nodosa; Fish community; Ichthyofauna; Seagrass; Vascular plant; Visual census.

\section{Introduction}

Seagrasses contribute significantly to the productivity of coastal areas of both temperate and tropical waters. These environments provide habitats for a wide variety of marine organisms, both plant and animal; these include meiofauna and flora, benthic flora and fauna, epiphytic organisms, plankton and fish (Phillips \& McRoy 1980). In the Canary Archipelago, the vascular plant Cymodocea nodosa (Ucria) Ascherson is the most common and abundant seagrass species (Afonso Carrillo \& Gil Rodríguez 1980; Reyes 1993; Reyes et al. 1995). This plant forms mixed beds with the green algae Caulerpa spp., generally located along the south and southeast coasts of the islands. This plant displays strong seasonality in the Mediterranean Sea (Peduzzi \& Vukovic 1990; Terrados \& Ros 1992; Mazella et al. 1993) and the Canary Archipelago (Reyes et al. 1995). Aspects of the morphology, anatomy and phenology of this seagrass have been discussed by Reyes et al. (1995) for the Canary Islands.

Examples exist of extensive damage to seagrass environments due to the inadvertent destruction of the population (Neverauskas 1987; Loflin 1995; Francour et al. 1999; Delgado et al. 1999; Short \& Neckles 1999; Guidetti 2001). The loss of important seagrass habitats has been followed by extensive studies (e.g. Thorhaug et al. 1987) of seagrass communities and an increasing awareness of the role these play in our coastal marine environment (Bortone 2000). This author (unpubl.) documented the impacts of a marina construction on the seagrass Halophila decipiens. Although Ros \& Romero (1992) have presented a methodological protocol for impact assessment for the construction of sports' harbours, no study has yet analysed the perturbation deriving from this type of construction on a Cymodocea nodosa seagrass bed. Hence, the aim of this paper is to evaluate the impact on the density, biomass and leaf length of a Cymodocea nodosa bed during an annual cycle, as well as on two descriptors of the associated fish communities. The null hypothesis is that the construction of the marina would not change these parameters. 


\section{Methods}

\section{Study locations}

Sampling of the seagrass beds was carried out at two locations from March 2001 to April 2002, every one to two months. The impact location (marina) was at El Berrugo $\left(28^{\circ} 55^{\prime} \mathrm{N} ; 13^{\circ} 35^{\prime} \mathrm{W}\right)$ and the control was at Playa Dorada $\left(28^{\circ} 55^{\prime} \mathrm{N} ; 13^{\circ} 36^{\prime} \mathrm{W}\right)$. The marina was built on a rocky platform, but also on a sandy bed covered by sparse patches of Cymodocea nodosa and Caulerpa prolifera. The construction of the marina began in September 2000; no data prior to the construction were available. The control bed was topographically and morphologically similar to the impact location, but sufficiently far away. The similarity of both beds has been documented by Pavón \& Salas et al. (2000). A map of the study sites is shown in Fig. 1. For each location and each time, we randomly selected three sites for sampling. This factor, therefore, represents the spatial replication of the factor 'Location'. Hence, a symmetrical post- impact sampling design has been selected.

\section{Sampling of seagrass beds}

For both locations random bed samples $(n=3)$ at each site were collected with the aid of a plastic container $(15 \mathrm{~cm} \times 26 \mathrm{~cm})$ penetrating $10 \mathrm{~cm}$ into the sediment, and a shovel. Containers were deployed 6 to $8 \mathrm{~m}$ deep. Samples were rinsed and filtered in situ to discard sediment and were kept in $4 \%$ formaldehyde seawater. In the laboratory, we measured shoot density and length of 30 randomly selected leaves from each sample. Biomass of Cymodocea nodosa and total biomass (Cymodocea nodosa + Caulerpa spp.) were obtained as dry weight (dw) after heating at $100{ }^{\circ} \mathrm{C}$ for 24 hr. (Sand \& Jensen 1975; Pérez \& Camp 1986; Reyes et al. 1995). All data were expressed as g. $\mathrm{m}^{-2}$.

\section{Fish surveys}

At each sampling time, three replicate 25-m line transects were randomly laid by boat during daytime hours (Brock 1982) at a depth of 6-10 m, approximately parallel to the shoreline, at each location (impact and control). The abundance of fish species was recorded by a SCUBA diver within $2 \mathrm{~m}$ of either side of the transects as described by Lincoln Smith (1988). Therefore an area equal to $100 \mathrm{~m}^{2}$ was selected as sampling area. The variables chosen to describe the fish community were: (1) species richness and (2) total number of individuals. They have been employed with satisfactory results in the Canary Archipelago (Bortone et al. 1991; Falcón et al. 1996).

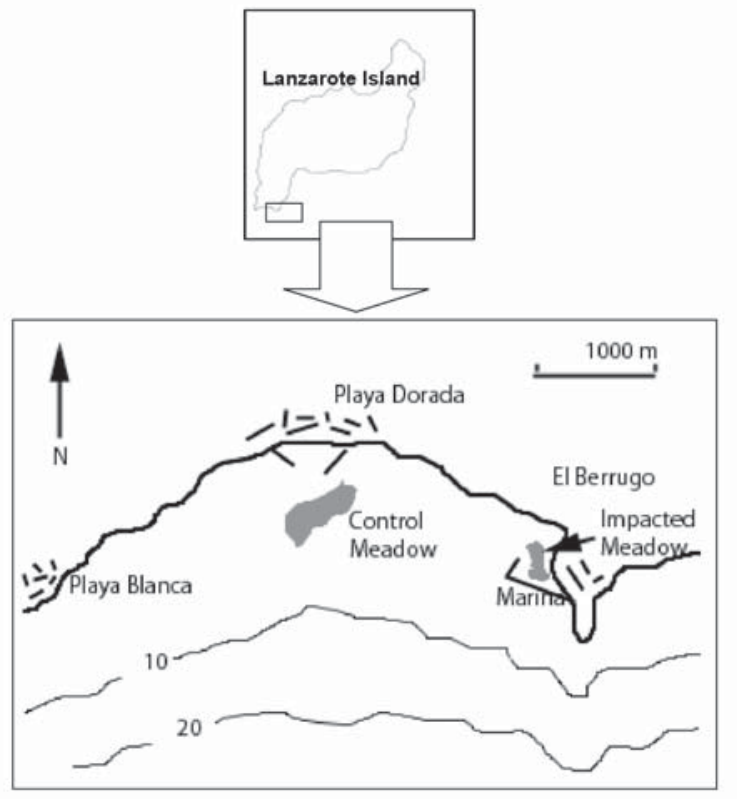

Fig. 1. Map of study locations. Berrugo (6-10 m deep) is the impacted location, while Playa Dorada is the control bed (7-11 $\mathrm{m}$ deep). Along-shore transport is from $\mathrm{E}$ to W. Surface water temperature ranged from $18.2^{\circ} \mathrm{C}$ to $23.1^{\circ} \mathrm{C}$, salinity was $36 \%$. Depth isolines are in $\mathrm{m}$.

\section{Light extinction}

To quantify the increase in the attenuation of light (PAR) in the location under impact from the operations derived from the construction of the marina, we measured in situ the light extinction coefficients $(k)$ using a LI-COR 4 radiometer, by means of measurements at 0,5 and $10 \mathrm{~m}$ deep. We followed the considerations of Margalef (1991).

\section{Statistical analyses}

A mixed three-way symmetrical analysis of variance (ANOVA) was used to compare data on density, biomass and leaf length over the different times, locations and sites. The factor 'Time of sampling' was considered random, while the factor 'Location' (= Impact vs Control) was fixed. 'Site' was nested within the factor 'Location'. This ANOVA design followed the instructions showed by Underwood (1997). Otherwise, an orthogonal symmetrical two-way ANOVA was employed to compare communities of fish (abundance and richness of total species) over the different times and both locations.

Although these designs are lesser equipped to detect an impact than a BACI design with multiple con- 
trol locations (Underwood 1997), it could be argued that the changes found at the impact location over time (compared with those at the control location) could be ascribed to this impact (Roberts 1996). The lack of beds with similar conditions to the impact location resulted in the selection of just one control location. A similar design was employed by Bortone (2000) in the study of the impact produced by the construction of a marina in Florida on a Halophila bed. The idea is to determine whether a statistically significant change in the density / biomass /leaf length of seagrass and the descriptors of the fish communities, occurred as a direct result of the marina construction thus giving rise to the comparison with a nearby control location.

Prior to the analysis, the data were examined by Levene's test for homogeneity of variances. Since no transformation rendered homogeneous variances, $\alpha$ was fixed at 0.01 , instead of 0.05 , since ANOVA is robust to heterogeneity of variances, particularly for large balanced experiments (Underwood 1981).

Finally, a $t$-test allowed us to compare the light attenuation coefficients for the two beds studied. All analyses were carried out using the SPSS 10.0.3 statistical package.

\section{Results}

Data on shoot density, biomass (Cymodocea nodosa and total) and leaf length (Figs. 2, 34 and 5, respectively) showed regular seasonal fluctuations for the control location, reaching maximum values in Spring Summer and minimums in Winter. The same pattern was observed for both descriptors of the fish communities within this control location (fish richness, Fig. 6, and total fish abundance, Fig. 7). On the other hand, the high value of fish abundance (14166 ind $100 . \mathrm{m}^{-2}$ ) detected in April 2001 was caused by the visualization of a dense group of the pelagic species Boop boops. Nevertheless, we have observed a decrease with time of the above-mentioned parameters and descriptors for the impact location. Thus, significant 'Time of sampling $\times$ Location (= Impact vs Control)' interactions were detected by the ANOVA models (Tables 1 and 2) for all the variables analysed.

No other significant interactions were obtained in the ANOVA designs for the density, leaf length and biomass of the studied seagrass beds (Table 1). Furthermore, and for these parameters, the spatial variability within both locations is low, since there was no significant $P$-value detected either for the interaction term ' $\mathrm{A} \times \mathrm{C}(\mathrm{B})$ ', nor for the main factor ' $\mathrm{C}(\mathrm{B})$ ' (Table 1).

Although the construction of the marina has pro-

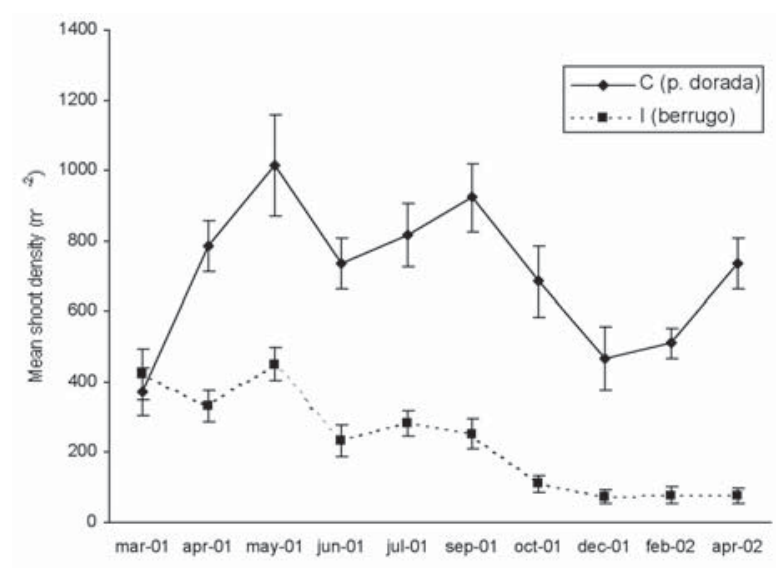

Fig. 2. Annual mean shoot density cycle for the impact and control locations. Error bars represent standard error of the means.

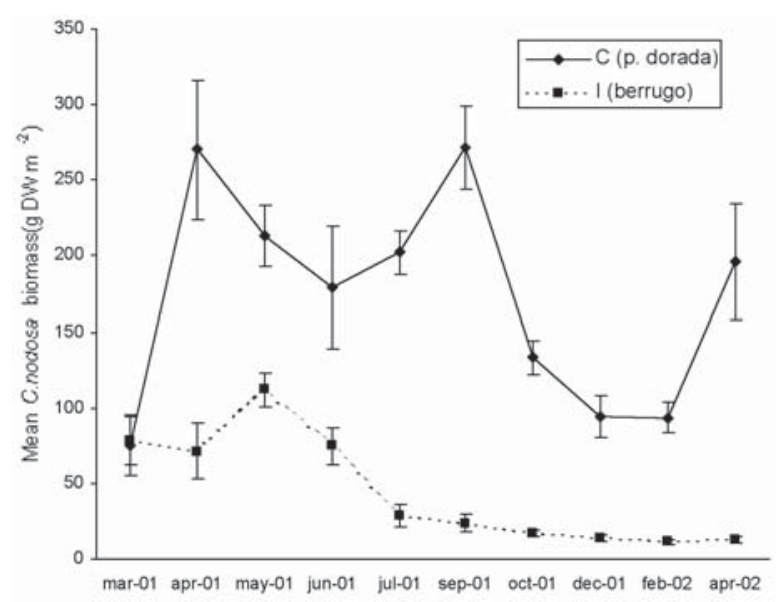

Fig. 3. Annual mean biomass cycle of the seagrass Cymodocea nodosa for the impact and control location. Error bars represent standard error of the means.

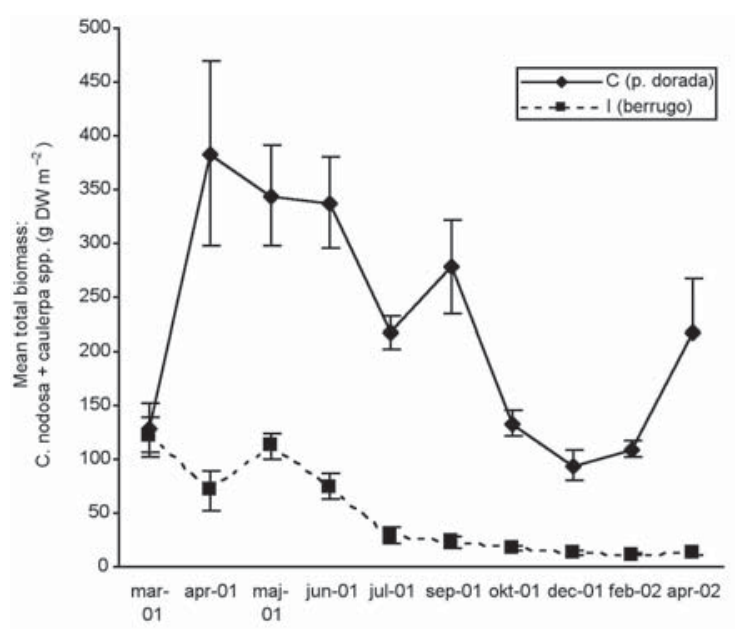

Fig. 4. Annual mean total biomass cycle for the impact and control locations. Error bars represent standard error of the means. 
Table 1. Results of the three-way ANOVA designs on the shoot density, biomass and leaf length. $\mathrm{B}=$ Location = Impact vs Control.

\begin{tabular}{|c|c|c|c|c|c|c|c|c|c|c|}
\hline \multirow[t]{2}{*}{ Source of variation } & \multirow[t]{2}{*}{ df } & \multirow[t]{2}{*}{$F$-ratio vs: } & \multicolumn{2}{|c|}{ Shoot density } & \multicolumn{2}{|c|}{ C. nodosa biomass } & \multicolumn{2}{|c|}{ Total biomass } & \multicolumn{2}{|c|}{ Leaf length } \\
\hline & & & MS & $F$ & MS & $F$ & MS & $F$ & MS & $F$ \\
\hline $\mathrm{A}=$ Sampling time & 9 & $\mathrm{~A} \times \mathrm{C}(\mathrm{B})$ & 373218.93 & $18.66^{*}$ & 34208.77 & $40.56^{*}$ & 81587.98 & $25.35 *$ & 27964.91 & 51.95 \\
\hline $\mathrm{B}=$ Location & 1 & No test & 9373999.61 & & 694562.48 & & 1469177.74 & & 785254.64 & \\
\hline $\mathrm{A} \times \mathrm{B}$ & 9 & $\mathrm{~A} \times \mathrm{C}(\mathrm{B})$ & 108417.57 & $9.90 *$ & 22638.16 & $26.84^{*}$ & 30457.34 & $9.46^{*}$ & 38741.84 & 71.96 \\
\hline $\mathrm{C}(\mathrm{B})=$ Site (location) & 4 & $\mathrm{~A} \times \mathrm{C}(\mathrm{B})$ & 146273.54 & 5.42 & 3357.26 & 3.98 & 2940.26 & 0.91 & 1058.74 & 1.96 \\
\hline $\mathrm{A} \times \mathrm{C}(\mathrm{B})$ & 36 & Error & 19992.15 & 0.46 & 843.37 & 0.21 & 3218.77 & 0.29 & 538.32 & 0.21 \\
\hline \multirow[t]{2}{*}{ Error } & 120 & 43320.65 & & & 3893.82 & & & 10834.71 & & \\
\hline & 1740 & & & & & & & & 2478.21 & \\
\hline
\end{tabular}

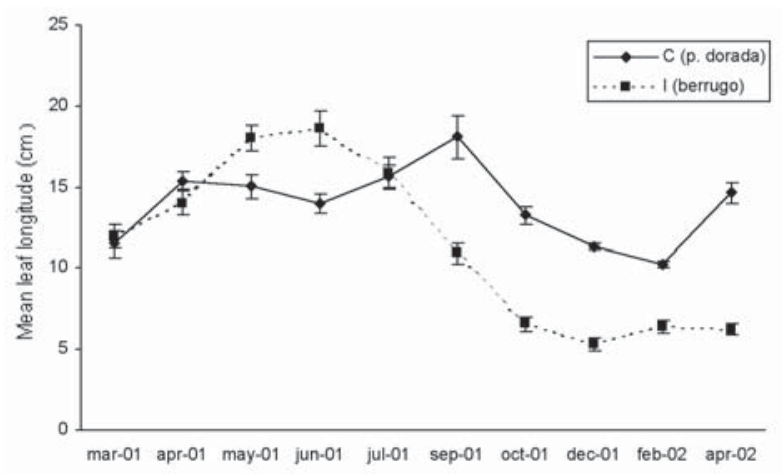

Fig. 5. Annual mean leaf length cycle for the impact and control location. Error bars represent standard error of the means.

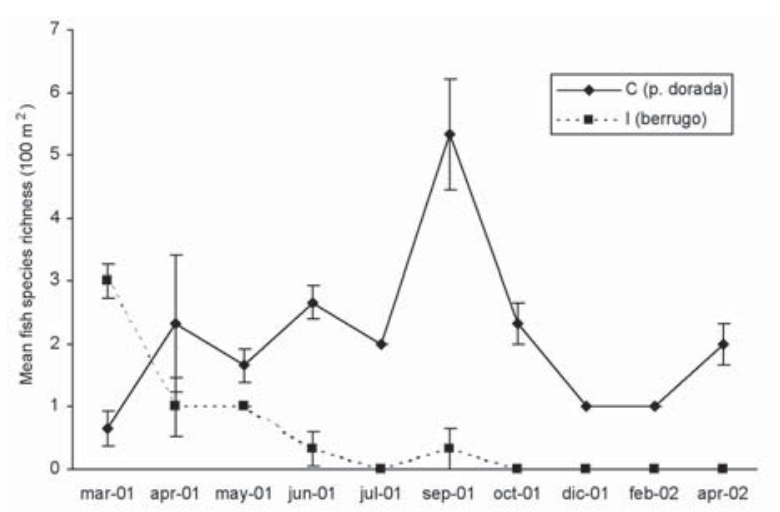

Fig. 6. Annual mean fish species richness cycle for the impact and control locations. Error bars represent standard error of the means.

duced a decrease in the overall fish community richness and abundance within the impact location, no fish species has displayed a strong change in mean abundance throughout the study period, as a result of the perturbation induced by the marina construction (Table 3 ). However, some fish species as Pagellus acarne and Bothus podas maderensis have been more frequently observed within the control bed (Table 3).

The penetration of light decreased (= increase in the attenuation coefficients) during the first part of the study
Table 2. Results of the two-way ANOVA models on the two selected descriptors of the fish assemblages.

\begin{tabular}{lcccccc}
\hline Source of variation & df & $F$-ratio vs: & Fish richness & \multicolumn{3}{c}{ Total fish abundance } \\
& & & MS & $F$ & MS & $F$ \\
\hline & & & & & & \\
A = Location & & & & & & \\
$(=$ Impact vs Control) & 1 & $\mathrm{~A} \times \mathrm{B}$ & 40.01 & $16.26^{*}$ & 4752.60 & 1.643 \\
$\mathrm{~B}=$ Sampling time & 9 & $\mathrm{~A} \times \mathrm{B}$ & 3.45 & 1.40 & 2930.23 & 1.01 \\
$\mathrm{~A} \times \mathrm{B}$ & 9 & Error & 2.46 & $5.47^{*}$ & 2893.04 & $392.72^{*}$ \\
Error & 40 & & 0.45 & & 7.36 & \\
& & & & & & \\
Total & 59 & & & & & \\
$*=P<0.01$. & & & & & & \\
& & & & & &
\end{tabular}

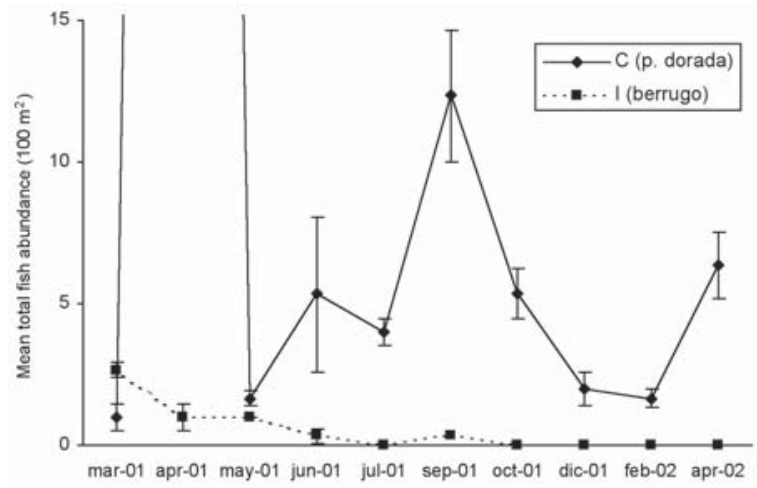

Fig. 7. Annual mean total fish abundance cycle for the impact and control location. Error bars represent standard error of the means.

(0.302 in March 2001 to 0.385 in April 2001) (Fig. 8) in the perturbed location. Further, the light extinction remained more or less constant over the rest of the sampling periods. However, the control location displayed a constant pattern throughout the overall research period, with a mean value of $0.163( \pm 0.02)$. A significant difference was obtained when we compared the light attenuation coefficients between both locations for the whole study $(t$-test $=14.69, P<0.0001)$. 
Table 3. Mean abundance $\left(n=3 ; 100 \mathrm{~m}^{2}\right)$ of fish populations at control $(\mathrm{C})$ and impact $(\mathrm{I})$ beds during the ten sampling times.

\begin{tabular}{|c|c|c|c|c|c|c|c|c|c|c|c|c|c|c|c|c|c|c|c|c|}
\hline \multirow[b]{2}{*}{ Species } & \multicolumn{2}{|c|}{$\operatorname{mar} 01$} & \multicolumn{2}{|c|}{ apr 01} & \multicolumn{2}{|c|}{ may 01} & \multicolumn{2}{|c|}{ jun 01} & \multicolumn{2}{|c|}{ jul 01} & \multicolumn{2}{|c|}{ sep 01} & \multicolumn{2}{|c|}{ oct 01} & \multicolumn{2}{|c|}{$\operatorname{dec} 01$} & \multicolumn{2}{|c|}{ feb 02} & \multicolumn{2}{|c|}{ apr-02 } \\
\hline & $\mathrm{C}$ & I & $\mathrm{C}$ & I & $\mathrm{C}$ & I & $\mathrm{C}$ & I & $\mathrm{C}$ & I & $\mathrm{C}$ & I & $\mathrm{C}$ & I & $\mathrm{C}$ & I & $\mathrm{C}$ & I & $\mathrm{C}$ & I \\
\hline Boop boops & - & - & 140 & - & - & - & - & - & - & - & - & - & - & - & - & - & - & - & - & - \\
\hline Bothus podas maderensis & 0.66 & - & 0.33 & - & - & - & - & - & - & - & 0.33 & - & 0.33 & - & - & - & - & - & - & - \\
\hline Canthigaster rostrata & - & - & - & - & - & 1 & - & - & 0.66 & - & 1 & - & 1 & - & - & - & - & - & - & - \\
\hline Diplodus annularis & - & - & - & 0.66 & - & - & - & 0.66 & - & - & - & 0.33 & 4 & - & - & - & - & - & - & - \\
\hline Lithognathus mormyrus & - & 0.66 & - & - & - & - & - & - & - & - & 2.66 & - & - & - & 2 & - & - & - & - & - \\
\hline Mullus surmuletus & - & 1 & 0.33 & - & - & - & - & 0.33 & - & - & 6 & - & - & - & - & - & - & - & - & - \\
\hline Pagellus acarne & 0.33 & - & 0.33 & 0.33 & 0.66 & - & 4 & - & 3 & - & - & - & - & - & - & - & 1.66 & - & 3 & - \\
\hline Sarpa salpa & - & - & - & - & 0.33 & - & - & - & - & - & - & - & - & - & - & - & - & - & - & - \\
\hline Sparisoma (Euscarus) cretense & - & 0.33 & - & - & - & - & 0.33 & - & - & - & 0.33 & - & - & - & - & - & - & - & - & - \\
\hline Stephanolepis hispidus & - & - & - & - & 0.33 & - & - & - & - & - & 0.66 & - & - & - & - & - & - & - & 3 & - \\
\hline Synodus spec. & - & - & 0.33 & - & - & - & - & - & 0.33 & - & 0.33 & - & - & - & - & - & - & - & - & - \\
\hline Xyrichthys novacula & - & 0.66 & 0.33 & - & 0.33 & 1 & 1 & - & - & - & 1 & - & - & - & - & - & - & - & 0.33 & - \\
\hline Total & 1 & 2.66 & 141.66 & 1 & 1.66 & 1 & 5.33 & 0.33 & 4 & 0 & 12.33 & 0.33 & 5.33 & 0 & 2 & 0 & 1.66 & 0 & 6.33 & 0 \\
\hline
\end{tabular}

\section{Discussion}

There is currently a lack of reports on the impact of human constructions on benthic communities through post-impact symmetrical sampling designs, as those showed by Underwood (1997). The present series of measurements provided enough evidence to reject the null hypothesis stated in our study. Thus, all the variables displayed a significant 'Time of sampling $\times$ Location' interaction term in the ANOVA designs, indicating that natural seasonal variability was different for the two locations studied. Although interactions at the site level within a location are ecologically important and show how communities experience patchiness over time (Roberts 1996), they contribute little to the general considerations in comparisons at the larger scale of impact and control locations.

Consequently, the operations deriving from the construction of the marina at El Berrugo (impact location) increased the attenuation of light in the water column and reduced the growth of plants in relation to a nearby

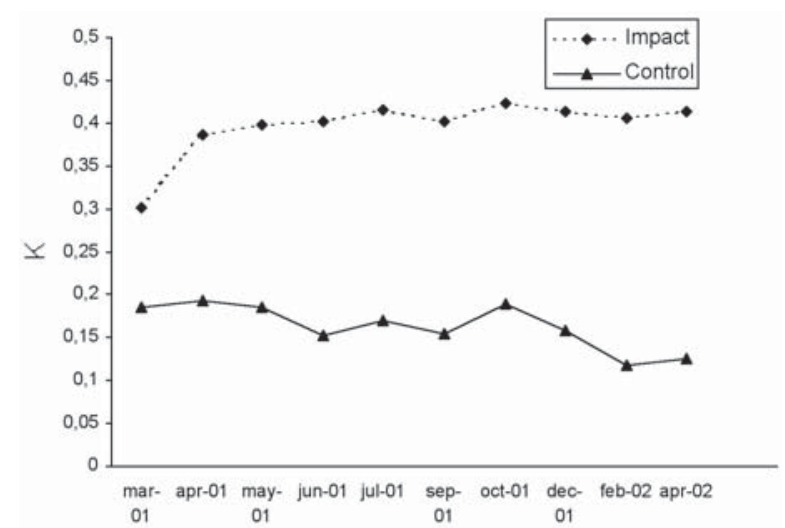

Fig. 8. Annual cycle of the light extinction coefficient (K) for the impact and control location. control area. This pattern was also observed in seagrass through shading assays in the Atlantic Ocean (Vermaat et al. 1993). Thus, we observed a decrease in the density and biomass of this bed with time. However, the control bed showed a seasonal pattern as described for the Cymodocea nodosa beds in the Mediterranean Sea (Peduzzi \& Vukovic 1990; Terrados \& Ros 1992) and the Canary Archipelago (Reyes et al. 1995). Moreover, the average leaf length experimented a fast increase at the beginning of the study (March 2001 to June 2001), as a possible morphological response of the plant to a decrease in the amount of light at the bottom during the initial phase of the marina construction. Afterwards, the mean leaf length decreased quickly. This may be attributed to the inhibition of plant growth as a response to the high turbidity at the perturbed location.

In addition, we observed a similar pattern for the fish communities. Therefore, the descriptors of the associated fish communities displayed seasonal behaviour in the control location. This type of tendency was obtained by Guidetti \& Bussoti (2000) for a Cymodocea nodosa bed in the Mediterranean Sea using a visual census technique similar to that employed by this study. However, the perturbed location showed a gradual decrease with time of these descriptors, as a result of the reduction of available seagrass biomass, since there is a strong correlation between the cycle of the biomass of this seagrass and the descriptors of the fish communities (Guidetti \& Bussotti 2000). Further, the observation of some fish species (Pagellus acarne and Bothus podas maderensis) which occurred more frequently within the control bed throughout the overall sampling period, cannot be explained in any ecological or biological way. 
Acknowledgements. We thank A.L. Luque and Javier Pérez for their help in the collection of the samples. Our thanks also go to Manolo Pérez the logistic support of a part of this study.

\section{References}

Afonso-Carillo, J. \& Gil-Rodríguez, M.C. 1980. Cymodocea nodosa (Ucria) Ascherson y las praderas submarinas o 'sebadales' en el Archipiélago Canario. Vieraea 8: 365376

Bortone, S.A. 2000. Seagrasses: monitoring, ecology, physiology and management. CRC Press, Boca Raton, FL, US.

Bortone, S.A., Van Tasell, J., Brito, A., Falcón, J.M. \& Bundrick, C.M. 1991. A visual assessment of the inshore fishes and fishery resources off El Hierro, Canary Islands: a baseline survey. Sci.Mar. 55: 529-541.

Brock, R.E. 1982. A critique of the visual census method for assessing coral reef fish populations. Bull. Mar. Sci. 32: 269-276.

Delgado, O., Ruiz, J., Pérez, M., Romero, J. \& Ballesteros, E. 1999. Effects of fish farming on seagrass Posidonia oceanica in a Mediterranean bay: seagrass decline after organic loading cessation. Oceanol. Acta 22: 109-117.

Falcón, J.M., Bortone, S.A., Brito, A. \& Bundrick, C.M. 1996. Structure and relationships within and between the littoral rock-substrate fish communities off four islands in the Canarian Archipelago. Mar. Biol. 125: 215-231.

Francour, P., Ganteaume, A. \& Poulain, M. 1999. Effects of boat anchoring in Posidonia oceanica beds in the PortCros National Park (north-western Mediterranean Sea). Aquat. Cons. 9: 391-400.

Guidetti, P. 2001. Detecting environmental impacts on the Mediterranean seagrass Posidonia oceanica (L.) Delile: the use of reconstructive methods in combination with 'beyond BACI'designs. J. Exp. Mar. Biol. Ecol. 260: 2739.

Guidetti, P. \& Bussotti, S. 2000. Fish fauna of a mixed bed composed by the seagrass Cymodocea nodosa and Zostera noltii in the Western Mediterranean. Oceanol. Acta 23: 759-770.

Lincoln Smith, M.P. 1988. Effects of observer swimming speed on sample counts of temperate rocky reef fish assemblages. Mar. Ecol. Prog. Ser. 43: 223-231.

Loflin, R.K. 1995. The effects of docks on seagrass beds in the Charlotte Harbor estuary. Fla. Sci. 58: 198-205.

Margalef, R. 1991. Ecología. Editorial Omega, Barcelona, ES.

Mazella,L., Scipione, M.B., Gambi,M.C., Buia, M.C., Lorenti, M., Zupo, V. \& Cancemi, G. 1993. The Mediterranean seagrass Posidonia oceanica and Cymodocea nodosa. A comparative overview. In: The 1st International Conference on the Mediterranean Coastal Environment, MEDCOAST'93, pp. 103-116. Antalya, TU.

Neverauskas, V.P. 1987. Monitoring seagrass beds around a sewage sludge in South Australia. Mar. Pollut. Bull. 18: 158-164.

Pavón-Salas, N.,Herrera, R.,Hernández-Guerra, A. \& Haroum, R. 2000. Distributional patterns of seagrasses in the Ca- nary Islands (Central - East Atlantic Ocean). J. Coastal Res. 16: 328-335.

Peduzzi, P. \& Vukovic, A. 1990. Primary production of Cymodocea nodosa in the Gulf of Trieste (Northern Adriatic Sea): a comparison of methods. Mar. Ecol.Prog. Ser. 64: 197-207.

Pérez, M. \& Camp, J. 1986. Distribución espacial y biomasa de las fanerógamas marinas de las bahías del Delta del Ebro. Inv. Pesq. 50: 519-530.

Phillips, R.C. \& McRoy, C.P. 1980. Handbook of seagrass biology: an ecosystem perspective. Garland STPM Press, New York, NY, US,

Reyes, J. 1993. Estudio de las praderas marinas de Cymodocea nodosa (Cymodoceaceae, Magnoliophyta) y su comunidad de epífitos, en el Médano (Tenerife, Islas Canarias). Ph.D. Thesis, Universidad de La Laguna, Tenerife, ES.

Reyes, J., Sansón, M. \& Afonso-Carrillo, J. 1995. Leaf phenology, growth and production of the seagrass Cymodocea nodosa at El Médano (South of Tenerife, Canary Islands). Bot. Mar. 38: 457-465.

Roberts, D.W. 1996. Landscape vegetation modeling with vital attributes and fuzzy systems theory. Ecol. Model.90: 175-184.

Ros, J.D. \& Romero, J. 1992. Impact assessment of the Spanish coast: Methodological protocol for environment evaluation focused on sports harbor building. Bull. Inst. Oceanogr. Monaco 11: 299-304.

Sand-Jensen, K. 1975. Biomass, net production and growth dynamics in an eelgrass (Zostera marina) populations in Vellerup Vig., Denmark. Ophelia 14: 185-201.

Short, F.T. \& Neckles, H.A. 1999. The effects of global climate change on seagrass. Aquat. Bot. 63: 169-196.

Terrados, J. \& Ros, J.D. 1992. Growth and primary production of Cymodocea nodosa (Ucria) Ascherson in a Mediterranean coastal lagoon: the Mar Menor (SE Spain). Aquat. Bot. 43: 63-74.

Thorhaug, A., Miller, B., Jupp, B.\& Bookers, F. 1985. Effects of a variety of impacts on seagrass restoration in Jamaica. Mar. Pollut. Bull. 16: 355-360.

Underwood, A.J. 1997. Experiments in ecology: their logical design and interpretation using analysis of variance. Cambridge University Press, Cambridge, UK.

Vermaat, J.E., Beijer, J.A.J., Gijlstra, R., Hootsmans, M.J.M. \& Philippart, C.J.M. 1993. Leaf dynamics and standing stocks of intertidal Zostera noltii Hornem. and Cymodocea nodosa (Ucria) Ascherson on the Banc d'Arguin (Mauritania). Hydrobiologia 258: 59-72.

Received 17 April 2002; Revision received 13 December 2002; Accepted 24 December 2002. Coordinating Editor: F. van der Meulen. 